\title{
Immersive narratives in web journalism. Between interfaces and virtual reality
}

\author{
Raquel Ritter Longhi \\ Universidade Federal de Santa Catarina/UFSC - Brasil \\ E-mail: raqlonghi@gmail.com
}

\begin{abstract}
This article discusses the concept of immersion in web journalistic narratives, verifying this recent trend of content production in two objects of analysis: "The Displaced"of the New York Times.com and "6 X 9: a virtual experience of solitary confinement"of The Guardian. Furthermore, through a bi-

of immersive narratives and on Virtual Reality (VR), the different types of content considered immersive in journalism and it analyzes the extent to which interfaces and VR visualization devices, such as glasses in Google Cardboards style, are able to provide an effective immersion in non-fiction narratives.
\end{abstract} bliographical research, it reflects on the conception

Keywords: immersive narratives; web journalism; interfaces; virtual reality.

\section{Narrativas imersivas no webjornalismo. Entre interfaces e Realidade Virtual}

\section{Resumo}

Discute a imersão nas narrativas webjornalísticas, verificando esta tendência da produção de conteúdos em dois exemplos recentes: "The Displaced"(New York Times.com) e "6 X 9: a virtual experience of solitary confinement"(The Guardian). Através de pesquisa bibliográfica, reflete sobre narrativas imersivas e em Realidade Virtual (RV) e analisa até que ponto as interfaces e os dispositivos de visualização de RV são capazes de proporcionar uma efetiva imersão nas narrativas de não-ficção.

Palavras-chave: narrativas imersivas; webjornalismo; interfaces; realidade virtual.

Data de submissão: 2017-06-16. Data de aprovação: 2017-12-04.

Este trabalho foi apresentado no 16. Encontro da SBPJor, em novembro de 2016.

A Revista Estudos em Comunicação é financiada por Fundos FEDER através do Programa Operacional Factores de Competitividade - COMPETE e por Fundos Nacionais através da FCT - Fundação para a Ciência e a Tecnologia no âmbito do projeto Comunicação, Filosofia e Humanidades (LabCom.IFP) UID/CCI/00661/2013.

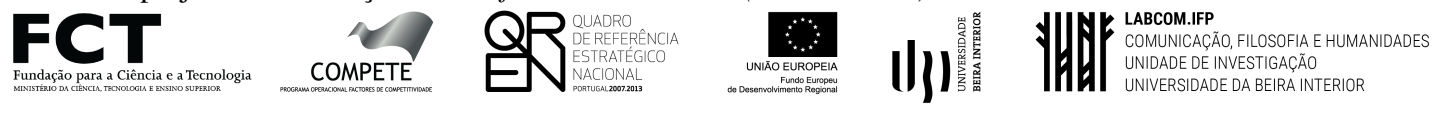




\section{Introduction}

$\mathrm{N}^{\mathrm{N}}$ a historic day in 1895 , the audience who watched a sequence of moving images projected onto a large screen had reactions like screams and rushing, due to the enormous effect caused by those unusual scenes. In January 2012, spectators who experienced immersive images for the first time in Nonny de la Peña's online projection of the documentary experiment in Virtual Reality (VR) "Hunger in Los Angeles" ${ }^{1}$ have had reactions like crying and shaking. The first story is well known: it concerns what is considered the inaugural public session of cinema, on December 28, 1895 , and it is part of the anecdotal of the seventh art; the second one is reported in the "Viewing the future? Virtual reality in journalism"report, published by the Knight Center in March 2016. (Doyle, Gelman and Gill, 2016).

What do they have in common? It can be said that the impact caused by innovative ways of visualizing and experimenting with images - and their narratives - are the confluence point of these two historic moments. Just as in the cinema, that in the late $19^{\text {th }}$ century brought an unusual kind of public reaction to moving images, the $21^{\text {st }}$ century virtual reality (VR) technology imposes new responses to experiencing the visualization of the world.

This article discusses the concept of immersion in web journalistic narratives, pointing out and verifying the recent trend of the production of immersive narratives in Virtual Reality. As object of analysis, it deepens the reflection about immersion in two recent contents of the reference web journalism: "The Displaced" ${ }^{2}$, of the NYTimes.com, published in November 2015 and "6 x 9: the virtual experience of solitary confinement" 3 , of The Guardian, from April 2016. The immersion will be discussed from two perspectives: a) conceptually, through a bibliographical survey, which also involves investigations about some conceptions of immersive narratives and narratives in VR and b) through the experience of visualization of the content with the VR visualization device in Google Cardboards ${ }^{4}$ VR Box style (Virtual Reality Glasses).

Indeed, Virtual Reality technology has been seen as a potential for narratives in digital media and various media organizations, especially online, are investing in these formats. Some authors think that Virtual Reality should be considered as a specific narrative, alongside theater, literature and cinema, where "each of these presents particularities that differentiate them from each other and determines their relative narrative forms, means of communication and displays of content in relation to story"(Aylett and Louchart, 2003, p. 2).

According to the aforementioned Knight Center report in 2015, about 12 organizations produced about 60 projects using 360-degree videos or three-dimensional - 3D animations to tell stories that can be experienced in VR.

The importance of this moment of experimentation with this new technology, and what it represents for the journalistic narratives, leads us to reflect on the potential of VR for journalism, to discuss the concept of immersion and to investigate the possible definitions for narratives in

1. The screening took place during the Sundance Film Festival in Utah, online with Los Angeles, when spectators used VR headsets to take part in the experience of a man having a diabetic attack.

2. Available:http://migre.me/ukTBS (Accessed November 2015).

3. Available: http://migre.me/ukTxP (Accessed April 2016).

4. The devices used were: VR glasses in Google Cardboard style and 3d Rift Virtual Reality glasses from the brand Vr Box, along with a remote control, both purchased by the author in June 2016. 
Virtual Reality. Along with this, discussing an issue that can be considered "technical", but which still has many questions: to what extent do interfaces and devices such as those used for the enjoyment of contents in VR allow a true and effective immersion?

\section{VR enters the picture}

For some time web journalism has been busy producing immersive narratives, in which the exploration of the expressive potentialities of hypermedia, especially graphic and sound, leads the user to a more in-depth reading experience. This type of narrative includes 360-degree images (static or moving), three-dimensional simulations with synthetic images and Virtual Reality. In all of them, the content can be viewed, or experienced - to use a term more suited to the type of fruition on screen - in different forms, which may or may not involve the use of devices such as headphones and special glasses - like Google Cardboard, Rift glasses and VR headsets. The idea is to conduct the user to experience stories in imagined or reproduced environments, in a way of total immersion with the content.

Considered the first documentary experience in VR, the already mentioned project "Hunger in Los Angeles", by Nonny de la Peña, was presented in the Sundance Film Festival in January 2012, when the spectators put on headphones and special glasses, the precursors of which today would be the world-renowned Rift glasses. "By immersing the user into another world, 'Hunger,' it was clear, went beyond a traditional documentary", as noted in the report "Viewing the Future? Virtual Reality in Journalism", published by the Knight Center in March 2016 (Doyle et al., 2016).

Indeed, Virtual Reality narratives, hitherto better known in the realm of videogames, began to occupy an important space in web journalism, bringing the focus to the immersive potentialities of the narrative. These forms of storytelling also include three-dimensional and 360-degree experiences in static and moving images (videos), which have also been defined as spherical (Doyle et al., 2016, p. 4) ${ }^{5}$. The moment is considered fundamental to the establishment and consolidation of narratives in VR, according to the report, which also contemplates, from this perspective, whether the VR will really be a feasible way to present the news $(2016$, p. 3). The text presents immersive and in virtual reality narrative forms that are conforming until this moment, which are: "virtual reality", in which environments are created that allow the user to feel as being present in alternative spaces; "augmented reality", which departs from the real world and overlaps objects and information; and "spherical"or "360-degree videos", which capture a scene in its entirety, where the users can view the content above, bellow, and around them.

More specifically entering the journalism, the first experience we have news of is in 2014, with the narrative "A harvest of change" 6 of the Des Moines Register. Produced entirely in third dimension, with the Unity tool, known for being widely used in video game production, the report shows a farm in the state of Iowa, United States, recreated in synthetic images modeled from photos, photographs and videos. However, the technique has been widely used in various types of nonfiction narratives, including infographics, large multimedia reporting and web documentaries, such as those produced by the National Film Board of Canada, among others. The Washington

5. The term will be used in this article as a synonym for "360 degrees", both in video and in photo.

6. Available: http://migre.me/tK6E9 (Accessed March 2016). 
Post, one of the main US newspapers, has featured 360-degree and VR products, such as the 360degree video of one of the US presidential race debates ${ }^{7}$ and a specific section for 360-degree images, the VR Room ${ }^{8}$. In Brazil, newspapers such as Folha de S. Paulo, Diário Catarinense, Zero Hora, Estadão, among others, have presented these types of contents, especially photographic and infographic. In Latin America, according to Longhi and Pereira, initiatives in this direction appear in April 2016, with the release of the VR content platform mobile app of the Clarín, the Clarín VR (Longhi and Pereira, 2016, p. 2).

Issues such as production costs, visualization devices, consumption habits and the physical sensations in the reading of this type of content already seem to be crucial for thinking the narratives in virtual reality, as it can be seen in the study by Doyle et al. (2016). The fact that it is still restricted to large journalistic groups is explained by the production cost, which is still very high.

\section{Immersion, Virtual Reality and the web journalistic narrative}

Although immersive narratives are currently "on the rise"in web journalism, the interest of "transporting"the reader, or user, to the place of the event is not new. Since video games popularized the idea of immersion in virtual worlds, as the term Virtual Reality became better known to the general public, journalism has been looking for ways to strengthen this kind of narrative content. This was achieved especially after the hypermedia and online environment of web journalism provided greater possibilities, both technological and expressive. And, precisely, the first attempts to put the reader on the scene, through web journalism, happen with the creation of newsgames, with the main objective of simulating situations and "worlds"to be "explored"by the readers/users. According to Marciano (2016), and nothing different from what is now being sought with VR contents, the newsgames proposed "to put the spectator on the place of the event", as exemplified in the early 2000s with products such as Food Import Folly, produced by The New York Times.com and made available in 2007, and Berlin Wall (Marciano, 2016). For De La Peña et al., the advent of computer games and virtual environments such as Second Life provided yet another opportunity for news re-creation. One of these games, Gone Gitmo, a virtual representation of the Guantanamo prison was created in 2007, consisting of a series of experiments with spatial narratives.

Coming from the field of arts, literature and cinema, to mention only a few, the idea of immersion takes place in web journalism in different "branches", especially in the field of narratives. An example is the term "immersive journalism", which has been widely used both in reference to content, and in research on narratives in Virtual Reality. A definition of the concept can be found in De La Peña et al: "(immersive journalism) is the production of news in a form in which people can gain first person experiences of the events or situation described in news stories"(De La Peña et al., n.d.). For Sadowski \& Stanney (2002), who revise authors on the subject, there are two main schools of thought about what immersion means in a virtual environment: the first one concerns a psychological state, and the second one is related to the ability of the computer to provide an illusion of an inclusive and surrounding reality to the participant of the immersive environments:

7. Available: http://migre.me/tw5hx (Accessed March 17 2016).

8. Available: https://www.washingtonpost.com/posttv/vrroom/index.html. (Accessed April 03 2016). 
Witmer and Singer (1998) define immersion as "a psychological state characterized by perceiving oneself to be enveloped by, included in, and interacting with an environment that provides a continuous stream of stimuli and experiences."They also suggest that factors that affect immersion include isolation from the physical environment, perception of self-inclusion in the VE, natural modes of interaction and control, and the perception of self-movement. With a different perspective, Slater and Wilbur (1997) define immersion as "the extent to which computer displays are capable of delivering an inclusive, extensive, surrounding, and vivid illusion of reality to the senses of the VE participant"(Sadowski Jr. and Stanney (2002).

The concept of immersion is, indeed, along with the concept of "presence", at the top of research on VR, according to the "Virtual Reality Journalism"report, published by the Columbia University's Tow Center in December 2015: "both, to varying degrees, seek to describe the feeling that one is experiencing an alternate reality by way of a virtual system"(Aronson-Rath, 2015). In the same research, Virtual Reality is defined as: "an immersive media experience that replicates either a real or imagined environment and allows users to interact with this world in ways that feel as if they are there"(Aronson-Rath, 2015). Surely the notions of immersion and presence will be fundamental to the understanding of immersive narratives and of narratives in Virtual Reality. In this article, we briefly explain this, emphasizing that these are concepts that should be more widely explored in future reflections on the subject.

The abovementioned authors Sadowski Jr. and Stanney (2002) attempt to define the concepts of immersion and presence in virtual environments based on some authors. Barfield and Hendrix (1995, apud Sadowski and Stanney, 2002) distinguish the presence in virtual worlds of the presence in the physical world as users believe they are in a different place from the one in which they physically find themselves during the course of experimentation generated by the computer. The same authors, in their bibliographic survey, bring Singer and Witmer (1997), for whom the presence is described as a sensorial flow that demands direct attention of the individual:

They suggest that presence be based on the interaction between sensory stimulations, environmental stimulations and the internal tendencies of the person. The individualpsychological perception of presence within a virtual environment is perceived principally as a by-product of the properties of immersion, and as being implicated in the virtual environment. Thus, presence in a virtual environment depends on the degree of attention of the user as they displace themselves in the physical environment. (Sadowski and Stanney, 2002)

De La Peña et al., on the other hand, emphasize that the academic studies that initially introduced the concept of presence in virtual environments date back to the 1990s; they defined presence as the strong feeling of being in the space represented by the virtual reality system. For the authors, it is a qualia, i.e., "... a quality of our experience that is impossible to describe, it is specifically the illusion of being in the virtually rendered space even though you know that you are not there"(De La Peña et al., n.d., p. 8).

What these studies show us implies understanding the presence and immersion in virtual worlds as notions that carry a paradox: at the same time that one has the sensation of presence in a 
different sphere from the physical world, the one in which the subject finds oneself at the moment of the virtual world experimentation, the presence in the virtual environment causes an awareness of belonging to an alternative space, a sensation stimulated by the user's need for attention. Such sensation can still find some "barriers"that may affect in different ways the perception of belonging to the virtual world: these can be in the interfaces and devices necessary for the enjoyment of the experience.

Philipe Quéau points out that the word "écran"(screen), which dates back to the Middle Ages meant, in its origin, a "protection", a "barrier". At the threshold of this notion, therefore, according to the author, one finds the understanding that "the screen masks more than it allows to see, and interposes itself more than it proposes"(Quëau, 1995, p. 103). In virtual environments, how can one imagine the screens and their immersion, taking into account the potential "barriers"?

\section{Interfaces and VR: the screen inside the screen}

We can no doubt reflect on the conception of "screen"on the scope of interface. In the virtual world, the screen would be "inside the screen", to be experienced as a space, and no longer as an inscription surface. In other words, one can think of VR as an interface without screens, but the screen existing as an interface. An interface that is effectively immersive, for it encompasses and integrates the user with the space.

In a study of literary creation in hypertext, and when reflecting on what would be "immersive interfaces,"Longhi pointed to the possibility that the interface may be at the same time what separates and what unites the subject with the content, serving as a gateway to the virtual world (at the time, the author considered different narrative forms) and providing a sense of immersion in an alternative space:

To such a state of "immersion", scholars call it the "daydreaming"state. The "immersion"is nothing more than the total surrender of the reader, listener or spectator, to the narrative of the respective environment to which they are watching, reading or listening. With the immersion, the concentration of all the senses occurs. This happens when we watch a movie or read a book, for example, and we transport ourselves entirely into the story presented there. It is the moment when we lose the notion of the objects through which the story is transmitted to us - the book or movie and movie projector, and we go completely into the story. (Longhi, 2002, p. 83)

Here is the concept of immersion as the total abandonment of the reader, user or spectator to an alternative world, different from the real world to which the individual belongs - or finds oneself. In this sense, we must consider the scope of the concept of immersion related to various means, or forms of representation - the book (printed), cinema (audiovisual), web journalism, long-form text, etc.

In order to continue with our reflection, it is necessary to take into account the possible meanings of the screen - as an element that separates, as an element that unites, as a space that is lived, and also as a barrier, in this case, inherent in some experiences of using VR devices, in this case, when they can constitute obstacles, interposing themselves between the user and the effective 
enjoyment of the content. To discuss more adequately about this subject, the next item deals with the experimentation of narratives in $v r$ using a specific visualization device.

\section{Experiencing journalism in VR}

In order to complement the analysis proposed in this article regarding journalistic narratives in virtual reality, we experimented with two web journalistic contents using a headset style visualization device, the "glasses"of the VR Box brand, made of plastic material and with straps for head support. We also used headphones, a device recommended by producers of this type of content to accompany the experience of wearing glasses.

The first visualized narrative was "6 x 9: a virtual experience of solitary confinement", produced by the British newspaper The Guardian and released in April 2016. To access the content on the mobile phone, you need to download the Guardian VR app.

In the VR Box glasses, which allow the user to adjust the distance of the lenses to the sides, back and forth, in order to better focus the image, the visualization found problems regarding the weight of the device on the head. This was probably caused due to the fact that the device's support straps were not able to be fully attached to the head, causing some discomfort. Being a kind of "prosthesis", and of an image that covers a spherical dimension, so to speak, and that requires in many moments the movement of the user, visualization equipment can cause the most diverse reactions, such as nausea sensations. These, although not as intense as in previous years, still constitute challenges to the VR hardware industry, according to Doyle et al. (2016, p. 18).

In the beginning of the narrative, the user is warned that the content has disturbing material, which can provoke reactions. "You should take this and your comfort into consideration before continuing,"says the text, and it ends up by reminding you that the user must be over 18 years old. As in the other contents that have been used in VR, also in the beginning of the experiment it is given the option for the user to choose the mode of visualization: whether through a VR headset type device, or through the mobile phone. In the case of desktop computers, or notebooks, the message will give the option for these devices. Once the device is chosen, a screen prompts you to insert the mobile phone into the device. In our experience, we can affirm that this "preparation"directly influenced the enjoyment of the content, a fact that is also allied to the aforementioned physical discomfort with the device. The visualization presented a small problem, which was the appearance of the "corners"of the equipment screen, which prevented, therefore, an immediate sensation of "being inside"the scene.

The initial images appear in the form of video in VR of the reconstitution of a prison cell: the proposal is that the users feel themselves inside of that prison. At the empty beginning, composed only by a toilet and a sink, a bed and a bench, gradually the environment is filled with other elements - books on the mattress, magazines on the floor, inscriptions on the walls, appearing as you "stroll"with your eyes around the environment. In the same way, off-screen sounds are gradually emerging, which represent testimonials from people who live in confinement or who have lived the experience of confinement. Ambient lighting varies according to day and night, and period changes can be easily perceived through the intensity of ambient light. 
In turn, the experience performed using only the mobile phone occurs in a differentiated way, especially in relation to the sensations. Firstly, the narrative only continues if the user moves the device. This is probably due to the fact that the device's gyroscope function is responsible for giving progression to the story. The use of headphones allows a better immersion, and at a certain point it is possible to "disconnect"from the "real"world, due to the strength of the narrative. Nothing is very different from what happens in other types of narrative, such as in literature and cinema, for example, or in reading a good journalistic long-form text.

Experimenting with the New York Times.com narrative "The Displaced,"using the same device, this narrative showed a greater immersion power, according to our experience. The content, the first to be produced especially in VR by the newspaper, is slightly more than 11 minutes, a datum informed at its beginning, and it can be viewed in the form of download or streaming (online), and it requires the specific app, in this case, the NYTVR. Just like the previous content, two alternatives are offered: visualize using Google Cardboard style devices or just through the mobile phone (or desktop computer, tablet, etc.). In our reading, we chose to use only the mobile phone, an I-phone 6S.

The first image, a destroyed classroom, probably by war, shows a boy writing on a blackboard. The sound of the chalk on the blackboard is clear and limpid. By being able to see more of the environment by moving your head up, down or sideways, the scene overview gives you an impression of really being in that setting. Unlike the previous experience, the sensation about the presence of the device is minimal, perhaps resulting from the strength of the image. A warning appears on the screen: you should move the mobile device to have a better viewing experience. The second image is a child pushing a boat through a kind of swamp, when a small text appears introducing data about refugees in the world, and warning that the narrative will tell the story of three children. The third image is a girl in another environment ravaged by war. Ruins contrast with her solid presence. The images alternate, and the off-screen sounds start - testimonials of the characters of the story, whose translations into English are showed on the screen, in the form of a moving text, which dances according to the movement conferred to the mobile phone. Gradually, the main characters are also identified: Oleg, 11, a refugee from Ukraine who returned to his hometown after the war; Chuol, 9, who was separated from her mother during a conflict, and her quest for survival in southern Sudan, and Hana, 12, a Syrian refugee living in a camp in Lebanon.

It is not our objective here to describe all of the content, but to emphasize the experience of narrative immersion, this is why we will only present this brief description of the beginning of the content. In general, such narratives present as an "introduction"some lines regarding the content, which widens as the narrative develops. There is much, however, much more to be thought out and ascertained about the experience of immersion of contents in VR.

\section{Final considerations}

The reactions to VR in 2012, and to that first movie projection in 1895, show the power of images and narratives to mobilize audience attention. This power is such that it causes strong, and even exaggerated, reactions seen from an extemporaneous perspective, of course - as it happened in both moments. Concerning possible reactions, by the way, it is interesting to observe The 
Guardian's warning in the introduction of the narrative examined in this article. Probably due to the current stage of development of this technology, there are still physical reactions to the contents, such as dizziness, nausea, among others. Obviously, The Guardian's warning is also a way of reinforcing the strength of the narrative that is being proposed: that it is about living a confining experience, which can be so strong as to emotionally affect the user.

Indeed, immersive and Virtual Reality journalism seems to have arrived with such force in the online environment that the power of immersion technologies for web journalistic narratives can already be contemplated. Is it possible, for example, at this moment, to establish the basis of what would be a narrative in Virtual Reality? Or, and before that, can Virtual Reality be thought of as a narrative form? Where does the interface and devices issue stand, in this sense? What role can they play in this kind of narrative?

This article sought to understand a little of the potential of VR for web journalistic narratives, investigating the extent to which interfaces and devices, such as those used for the enjoyment of these contents, allow a true and effective immersion. The question is, in this sense, on what stage, effectively, are we in this moment of the experiments in contents and immersive narratives and in VR of web journalism?

On the other hand, the simple interaction with journalistic products, using the gyroscope function of smartphones, or the movements of sliding the fingers on a tablet, or the arrows (on the screen) and through the computer mouse, could not provide an equally or perhaps more effective immersion sensation? It cannot be disregarded yet that, as literature and cinema have shown us, stories told through words or images and sounds, are capable - even today, of making us completely immerse in other worlds.

And finally, one must emphasize that immersion in the story, when it is possible to "detach"from the "real"world, occurs due to the strength of the narrative. This, traditionally, is formed by two main axes: the content (what is said) and the form (how it is said) (Longhi, 2002). The narratives in VR, right away, point to another axis, the one of experimentation, since the reader, now a user, should use devices to enjoy the story. But this is another story.

\section{References}

Aronson-Rath, R.; Milward, J.; Owen, T. \& Pitt, F. (2015). Virtual reality journalism. Tow Center for Digital Journalism at Columbia University. Available: https://towcenter.gitbooks.io/virtua 1-reality-journalism/content/index.html (Accessed March 2016).

Aylett, R. \& Louchart, S. (2003). Towards a narrative theory of virtual reality. Virtual Reality, G. Subsol (ed.), 1: 2-9.

De La Peña, N. et al. (s.d.). Immersive journalism: immersive virtual reality for the first person experience of news. Available: http://migre.me/uk28n. (Accessed June 2016).

Doyle, P.; Gelman, M. \& Gill, S. (2016). Viewing the future? Virtual reality in journalism. Knight Foundation. Available: www.knightfoundation.org/media/uploads/publication_pdfs/VR_rep ort_web.pdf (Accessed March 2016). 
Longhi, R. R. (2015). Metáforas e labirintos: a narrativa em hipertexto na internet. Online. Available: http://nephijor.ufsc.br/wordpress/wp-content/uploads/2015/09/livrodissert-11.pdf (Accessed April 2016).

Longhi, R. R. \& Pereira, S. da C. (2016). Do panorama à realidade virtual: como o ciberjornalismo está criando narrativas imersivas. 16 Congresso da Associação Latino-americana de Investigadores da Comunicação - ALAIC. Cidade do México, outubro de 2016. Available: http://alaic2016.cua.uam.mx/documentos/memorias/GT16.pdf (Accessed December, 2016).

Marciano, C. (2016). Jogando ética: newsgames de letramento no ensino de deontologia jornalísticas. Dissertação de mestrado defendida no Programa de Pós-Graduação em Jornalismo da Universidade Federa de Santa Catarina. Florianópolis.

Sadowski \& Stanney (2002). Measuring and managing presence in virtual environments. Available: http://web.cs.wpi.edu/gogo/courses/imgd5100/papers/Sadowski_HVE_2002.html (Accessed May 2016). 